Didaché: Journal of Christian Education

Vol. 1, No. 2 (2020): 117-140

journal.sttsimpson.ac.id/index.php/DJCE

e-ISSN: 2722-8584

DOI : 10.46445/djce.v1i2.349

Published by: Sekolah Tinggi Teologi Simpson Ungaran

\title{
Penerapan Model Think-Pair and Share dalam Meningkatkan Hasil Belajar PAK pada Siswa SMP
}

\author{
Bongsu Parhusip, Hasahatan Hutahaean*, Elda Theresia \\ Sekolah Tinggi Teologi Sumatera Utara \\ *Email: hasea2014@gmail.com
}

\begin{abstract}
Write This research is a Classroom Action Research (CAR) which aims to see the results of PAK learning through the application of the Think-Pair-Share Technique Cooperative Learning Model Application. The subjects of this study were students of class VIII SMP Parulian 3 Medan with 30 students as respondents. The subject of study is Life of Gratitude. The research instrument was a test given to students as many as 11 questions for the first cycle and 15 questions in the second cycle. Each cycle is carried out with different materials according to the learning limits at school. Each cycle consists of a planning stage, an action stage, an observation stage, and a reflection stage. In the first cycle, there was an increase in student PAK learning outcomes, namely $46.39 \%$ with the incomplete assessment category. Whereas in cycle II, there was also an increase in student PAK learning outcomes, namely $84.88 \%$ with the complete assessment category. This means that the application of Think-Pair-Share Learning can improve SMP students' PAK learning outcomes.
\end{abstract}

Keywords: Classroom Action Research; learning outcomes; Think-Pair-Share

\begin{abstract}
Abstrak
Penelitian ini merupakan Penelitian Tindakan Kelas (PTK) yang bertujuan melihat hasil belajar PAK melalui Penerapan Model Pembelajaran Kooperatif Tipe Think-Pair and Share. Subjek penelitian ini siswa kelas VIII SMP Parulian 3 Medan dengan jumlah responden 30 siswa. Adapun subjek belajar adalah Hidup Bersyukur. Instrumen penelitian ini adalah test yang diberikan kepada siswa sebanyak 11 soal untuk siklus I dan 15 soal pada siklus II. Setiap siklus dilaksanakan dengan materi yang berbeda sesuai dengan batas pelajaran di sekolah. Setiap siklus terdiri dari tahap perencanaan, tahap tindakan, tahap pengamatan, dan tahap refleksi. Pada siklus I, terdapat peningkatan hasil belajar PAK siswa yakni 46,39\% dengan kategori penilaian belum tuntas. Sedangkan pada siklus II, juga terdapat peningkatan hasil belajar PAK siswa yakni $84,88 \%$ dengan kategori penilaian tuntas. Ini berarti penerapan Pembelajaran Tipe Think-Pair and Share dapat meningkatkan hasil belajar PAK siswa SMP.
\end{abstract}

Kata kunci: Hasil Belajar; penelitian tindakan kelas; Tipe Think-Pair and Share 


\section{Pendahuluan}

Pendidikan Agama Kristen adalah mata pelajaran yang wajib diberikan mulai dari anak-anak Sekolah Minggu sampai Perguruan Tinggi. Sebagai orang Kristen, khususnya pembelajaran PAK tidak henti-hentinya dipelajari untuk membentuk pribadi manusia sebagai orang yang takut akan Tuhan dan mengenal Yesus Kristus dalam kehidupannya di rumah dan masyarakat. Dalam perjalanan perkembangan gereja juga bersinggungan dengan kegiatan pembelajaran PAK di masyarakat (Band. Hutahaean, 2016, p. 27). Oleh karena itu, pada umumnya pendidikan adalah salah satu bentuk perwujudan kebudayaan manusia yang dinamis dan sarat perkembangan. Di mana perubahan dan perkembangan pendidikan adalah hal yang memang seharusnya terjadi sejalan dengan perubahan budaya kehidupan (Hamalik, 2007, pp. 79-80).

Pendidikan Agama Kristen juga merupakan proses belajar mengajar yang mendidik dan membimbing setiap siswa dalam semua tahap pertumbuhannya. Yang dengan berfokus pada Kristus sebagai teladan Guru yang Agung dan perintah/Amanat Agung Yesus Kristus, untuk menjadikan semua murid Tuhan Yesus Kristus yang dewasa rohani berdasarkan pada Firman Tuhan dan berkuasa (Mat. 28:18-20).

Dalam kekristenan, Pendidikan Agama disebut dengan Pendidikan Agama Kristen (PAK). Pazmino menyatakan bahwa Pendidikan Agama Kristen merupakan upaya ilahi dan manusiawi yang dilakukan secara bersahaja dan berkesinambungan, untuk memberikan pengetahuan, nilai-nilai, sikap-sikap, keterampilan, sensitivitas, tingkah laku yang konsisten dengan iman Kristen. Pendidikan juga terus mengupayakan perubahan dan perubahan pada karakter personal maupun komunal, secara terstruktur oleh kuasa Roh Kudus, sehingga terus bersesuaian dengan kehendak Tuhan Yesus seperti ditulis Kitab Suci, serta upaya terus-menerus untuk mewujudkannya (Pazmino, 2003, p. 137).

Selain itu adapun fungsi dari Pendidikan Agama Kristen yaitu: (1) Memampukan peserta didik memahami kasih dan karya Allah dalam kehidupan sehari-hari, (2) Membantu peserta didik mentransformasikan nilainilai kristiani dalam kehidupan sehari-hari. Sedangkan tujuan Pendidikan Agama Kristen itu sendiri adalah: (1) Untuk mengajak, membantu, menghantar, seseorang untuk mengenal kasih Allah yang nyata dalam Yesus Kristus, (2) Untuk membawa anak didik percaya dan menerima Yesus Kristus sebagai Tuhan dan Juruselamat hidupnya, (3) Untuk menambahkan nilai-nilai 
Kristiani juga memberikan wawasan dan pengetahuan keberanian firman Tuhan secara kognitif (pengetahuan), afektif (sikap), dan psikomotor (keterampilan).

Sedangkan untuk meningkatkan mutu Pendidikan Agama Kristen di Sekolah Menengah Pertama, guru harus dapat menggunakan alat yang murah dan efisien meskipun sederhana dan bersahaja tetapi merupakan keharusan dalam upaya mencapai standar kompetensi sebagai tujuan pembelajaran yang diharapkan mampu dicapai oleh setiap peserta didik. Pengalaman penggunaan satu metode dalam penelitian Rifai (2017, pp. 185-189) pada siswa SMP juga menghasilkan peningkatan hasil belajar baik di bidang afektif, psikomotorik maupun kognitif. Di samping menggunakan alat-alat yang terjadi, kompetensi guru sangat berpengaruh dalam penerapan metode mengajar dalam kelas bagi Saifulloh perlu menyesuaikan kultur belajar terhadap siswa yang disepakati mulai dari kepala sekolah, guru hingga tenaga kependidikan (Saifulloh, Muhibbin, \& Hermanto, 2012, pp. 214-215).

Masalah mendasar yang dikeluhkan guru PAK di sekolah-sekolah umum di mana mata pelajaran Pendidikan Agama Kristen yang mendapat alokasi waktu belajar lebih sedikit dibanding dengan pelajaran-pelajaran yang lain, padahal materi agama mencakup banyak aspek, yang meliputi pengenalan yang benar akan anak Allah, membentuk Iman dan berakhlak. Hal ini ditandai dengan rendahnya kemampuan siswa dalam memberikan pendapat dalam topik pembelajaran yang sedang dibahas, rendahnya kemampuan siswa dalam hal bertanya pada guru, dan juga rendahnya kemampuan siswa untuk saling bekerja sama dengan peserta didik lainnya. Maka dengan waktu belajar yang minim tersebut tujuan pembelajaran PAK itu sulit tercapai dan hasil yang dicapai dalam pembelajaran PAK masih tergolong rendah.

Di samping itu juga ketidak berhasilan siswa dalam belajar PAK, terlihat dari seorang guru PAK yang hanya menggunakan metode ceramah, cerita, dalam setiap topik pelajaran. Dalam tulisan Hutahaean menyatakan bahwa guru hanya meningkatkan penguasaan materi yang diterapkan sehingga siswa tidak terlibat aktif dalam proses belajar mengajar yang mengakibatkan kurangnya minat siswa dalam proses pembelajaran PAK di kelas (Hutahaean, 2019). Di samping itu, setiap siswa kurang terlibat aktif dalam proses pembelajaran PAK yang sedang berlangsung, sehingga banyak siswa yang merasa bosan dan tidak lagi aktif mengikuti pembelajaran di kelas. Tugas guru tidak hanya sebagai pengarah ataupun sebagai fasilitator dalam proses 
pembelajaran. Naibaho menambahkan bahwa sebagai fasilitator guru diharapkan memberi dorongan, memotivasi, tentu mendoakan dan juga mengusahakan suasana belajar yang menyenangkan untuk siswa (Naibaho, 2018, p. 80). Akan tetapi, pembelajaran yang seperti ini masih belum tersampaikan ataupun belum diterapkan di sekolah khususnya siswa kelas VIII SMP Parulian 3 Medan.

Berdasarkan hasil wawancara dengan guru PAK SMP Parulian 3 Medan menyatakan bahwa selama ini telah diupayakan untuk mengoptimalkan hasil belajar siswa dalam pembelajaran PAK. Namun, hal ini tercermin adanya hasil belajar PAK siswa yang masih rendah saja. Hal ini dilihat dari tingkat ketuntasan klasifikasi dari 30 siswa di antaranya 15 orang siswa yang memperoleh nilai 7,00-8,00 (30\%) yang bisa dikategorikan lulus, 10 orang siswa memperoleh nilai 6,90-5,00 (27\%) dan 5 siswa yang memperoleh nilai 4,90 kebawah $(43 \%)$ masih jauh dari standar kelulusan yang sudah diterapkan yaitu 7,50 sebagai standar kelulusan untuk bidang studi PAK yang dilihat dari ulangan harian, tengah semester, serta akhir semester.

Oleh sebab itu, berdasarkan hasil observasi bahwa dilihat faktor penyebab rendahnya hasil belajar PAK siswa kelas VIII SMP Parulian 3 Medan adalah guru yang tidak memiliki kemampuan untuk menciptakan situasi belajar mengajar yang mampu memberikan dorongan belajar kepada siswa. Melihat hal tersebut, guru diharapkan mampu menciptakan proses belajar mengajar yang efektif dan efisien yaitu dengan menggunakan metode, media dan pendekatan pembelajaran yang sesuai dengan karakteristik yang dimiliki siswa sehingga akan tercipta proses belajar mengajar yang efisien dan menyenangkan.

Salah satu alternatif model pembelajaran yang dapat dikembangkan dalam proses pembelajaran adalah model pembelajaran kooperatif Think-PairShare (TPS). Think-Pair-Share merupakan struktur sederhana dan terdiri atas 3 langkah utama yaitu Think (berpikir), Pair (berpasangan), Share (berbagi). Kaddoura menjelaskan bahwa model pembelajaran kooperatif TPS atau berpikir berpasangan berbagi ini merupakan model pembelajaran yang dirancang untuk mempengaruhi pola interaksi siswa. TPS memberi siswa kemampuan untuk bekerja sendiri selanjutnya siswa berpasangan dengan salah satu rekan dalam kelompok dan berdiskusi dengan pasangannya kemudian salah satu dari anggota kelompok membagikan hasil diskusinya di depan kelas (Kaddoura, 2013, pp. 7-9). 


\section{Kriteria Pemilihan Model}

Model pembelajaran dipilih untuk menekankan kenyataan hidup manusia yang terletak pada kesadaran individu untuk memuaskan perhatian dan berusaha mendorong kemandirian agar manusia semakin sadar dan bertanggung jawab terkhusus pada siswa tersebut (Tafonao, 2018, p. 108). Adapun hal yang harus diperhatikan dalam pemilihan model ini menurut Trianto yaitu 1) Model pembelajaran dipilih untuk mampu menentukan arah dalam pencapaian sebuah tujuan; 2) Model pembelajaran dipilih untuk membantu siswa bertanggung jawab dalam prilakunya di dalam lingkungan kelas. 3). Model pembelajaran dipilih untuk sebuah kerangka berfikir sebagai bentuk penelitian ilmiah. 3). Model pembelajaran dipilih untuk membantu siswa mengumpulkan data untuk mengorganisasikan informasi tentang hasil belajar (Trianto, 2014, pp. 56-59).

Menurut Radhakrishna TPS adalah suatu metode pembelajaran yang menggiring pola kooperatif antar siswa sehingga memberi siswa waktu untuk berfikir dan merespon serta saling bantu satu sama lain. Model ini memperkenalkan ide waktu berpikir atau waktu berpikir atau waktu tunggu yang menjadi faktor kuat dalam meningkatkan kemampuan siswa dalam merespon pertanyaan (Radhakrishna \& Chikthimmah, 2012). Pelajaran kooperatif model ini relatif lebih sederhana karena tidak menyita waktu yang lama untuk mengatur tempat didik ataupun menggelompokkan siswa. Pembelajaran ini melatih siswa untuk berani berpendapat dan menghargai pendapat teman. Menurut penelitian awal dari Kothiyal dan kawan-kawan, model pembelajaran TPS memberikan siswa kesempatan untuk bekerja sendiri serta bekerja sama dengan orang lain dan mampu memberikan peningkatan sebesar $83 \%$ terlibat dalam diskusi kelas (Kothiyal, Majumdar, Murthy, \& Iyer, 2013, pp. 141-143). Dengan model ini memungkinkan hanya satu siswa maju dan membagikan hasilnya ke seluruh kelas dan memberikan kesempatan sedikitnya delapan kali lebih banyak kepada setiap siswa untuk dikenali dan menunjukkan partisipasi mereka kepada orang lain. Penelitian Awad Raba menunjukkan keberhasilan metode pembelajaran TPS dalam meningkatkan komunikasi lisan antar siswa, dan efektif dalam meningkatkan kafasihan siswa dalam berbicara, mungungkapkan pendapat serta kerjasama antar siswa dan dengan guru (Raba, 2017, p. 20).

Pada lingkup kelas dan kemudian antar kelompok belajar siswa, perlu ditumbuhkan gairah saling menolong dan menopang, saling menghargai dan 
bukan kompetisi semu. Siswa harus diberi pengertian bahwa orang yang memberi ilmu justru lebih memperkaya orang yang memberinya. Dalam pendidikan Kristen upaya-upaya ini bermuara sebagai implikasi pendidikan Kristen sebagai cermin dan interpretasi kasih Allah (Tety \& Wiraatmadja, 2017). Sebab model TPS adalah pembelajaran dengan mengutamakan kerjasama siswa serta disusun guna mempengaruhi gairah interaksi siswa. Karena itu, pola ini cocok dijadikan sebagai salah satu dalam mewujudkan filosofi pendidikan Kristen seperti pendapat Tety dan Wiraatmadja tersebut. Pembelajaran TPS dimulai dengan pertanyaan guru terkait subjek, selanjutnya meminta peserta didik mengajukan pertanyaan kepada guru. Setelah itu guru meminta siswa berpasangan mendiskusikan subjek pelajaran dan selanjutnya hasil diskusi setiap pasangan dibicarakan dengan pasangan seluruh kelas. Semua resitasi atau diskusi membutuhkan pengaturan untuk mengendalikan kelas secara keseluruhan, dan prosedur yang digunakan dalam TPS dapat memberikan siswa lebih banyak waktu untuk berpikir, untuk merespon dan saling membantu. TPS merupakan model pembelajaran perpaduan antara belajar mandiri dan belajar secara berkelompok berpasangan. Model TPS menggunakan metode diskusi berpasangan yang dilanjutkan dengan diskusi kelompok. Dengan model pembelajaran ini, siswa dilatih bagaimana mengutarakan pendapat dan siswa juga belajar menghargai pendapat orang lain dengan tetap mengacu pada materi/tujuan pembelajaran (Prahl, 2017, p. 5).

Dengan demikian model pembelajaraan think pair share merupakan salah satu model pembelajaran kooperatif yang memberi kesempatan pada siswa untuk bekerja sama dengan orang lain . Kegiatan berpikir, berpasangan, dan berbagi dalam model think pair share memberikan keuntungan. Siswa secara individu dapat 'mengembangkan dan merangsang pemikirannya masingmasing agar lebih kreatif'(Tendrita, Mahanal, \& Zubaidah, 2016, p. 287) karena adanya waktu berpikir (think pair share), sehingga kualitas jawaban juga dapat meningkat, selain itu interaksi antara siswa juga lebih mudah.

Berdasarkan hasil observasi di VIII SMP Parulian 3 Medan dalam bidang studi PAK kelas VIII untuk Tahun Ajaran 2018-2019 untuk itu guru mata pelajaran PAK membutuhkan model-model pembelajaran yang inovatif dalam melaksanakan proses belajar mengajar. Dan oleh karena itu, perlu dilakukan penelitian tentang penerapan model pembelajaran kooperatif tipe TPS dalam meningkatkan hasil belajar PAK siswa kelas VIII SMP Parulian 3 Medan. Usaha tersebut akan menggunakan penelitian tindakan kelas untuk memecahkan 
masalah pembelajaran guru serta meningkatan mutu hasil pembelajaran dengan berbagai cara baru yang perlu diterapkan (Widayati, 2014, p. 89). Dengan demikian akan diketahui signifikansi model TPS dan dinamika penerapannya dalam meningkatkan hasil belajar.

\section{Metode}

Tuliskan Penelitian ini bertujuan untuk meningkatkan kemampuan hasil belajar siswa VIII SMP Parulian 3 Medan dengan menggunakan model pembelajaran Think Pair and Share (TPS). Sesuai dengan tujuan penelitian, rancangan yang akan digunakann dalam penelitian ini adalah rancangan penelitian tindakan kelas atau classroom action research. Merujuk pada Khasinah, adapun langkah penelitian ini adalah identifikasi masalah di kelas. Kedua, memilih metode yang tepat sesuai kondisi kelas. Ketiga, memilih pelajaran yang hendak diajarkan. Keempat, mengumpulkan data yang dibutuhkan untuk menjawab pertanyaan. Kelima, menganalisa data, dan jika belum menjawab pertanyaan masalah maka perlu dilakukan lagi (siklus kedua). Keenam, merangkum data yang menjadi jawaban masalah/pertanyaan dan harapan penelitian. Sedangkan ketujuh, mendiskusikan hasil penelitian dengan kolega, baik rekan peneliti atau pembimbing dan suvervisor penelitian (Khasinah, 2015, pp. 110-111). Subjek dalam penelitian ini adalah siswa kelas VIII SMP Parulian 3 Medan yang berjumlah 30 orang. Dalam kaitannya dengan penelitian ini teknik pengumpulan data yang digunakan adalah teknik tes subjektif. Observasi dilakukan untuk mengetahui kekurangan atau kesulitan siswa dengan media yang digunakan pada proses pembelajaran, sedangkan catatan lapangan digunakan untuk mencatat proses pembelajaran yang berlangsung untuk digunakan sebagai bahan pertimbangan untuk melakukan tindakan. Ada pun pelaksanaan tindakan ini adalah dengan menerapkan model pembelajaran TPS untuk meningkatkan hasil belajar siswa kelas VIII SMP Parulian 3 Medan untuk topik bahasan "Hidup Bersyukur." Pelaksanaan tindakan terdiri atas beberapa siklus terdiri atas tahap perencanaan tindakan, pemberian tindakan, observasi, dan refleksi atau analisa. Hingga tujuan penelitian tercapai. Berikut ini alur penelitian menggunakan model think-Pair-share (TPS) secara sistematis (Arikunto, 2006). 
Gambar 1. Siklus Model Penelitian Tindakan Kelas

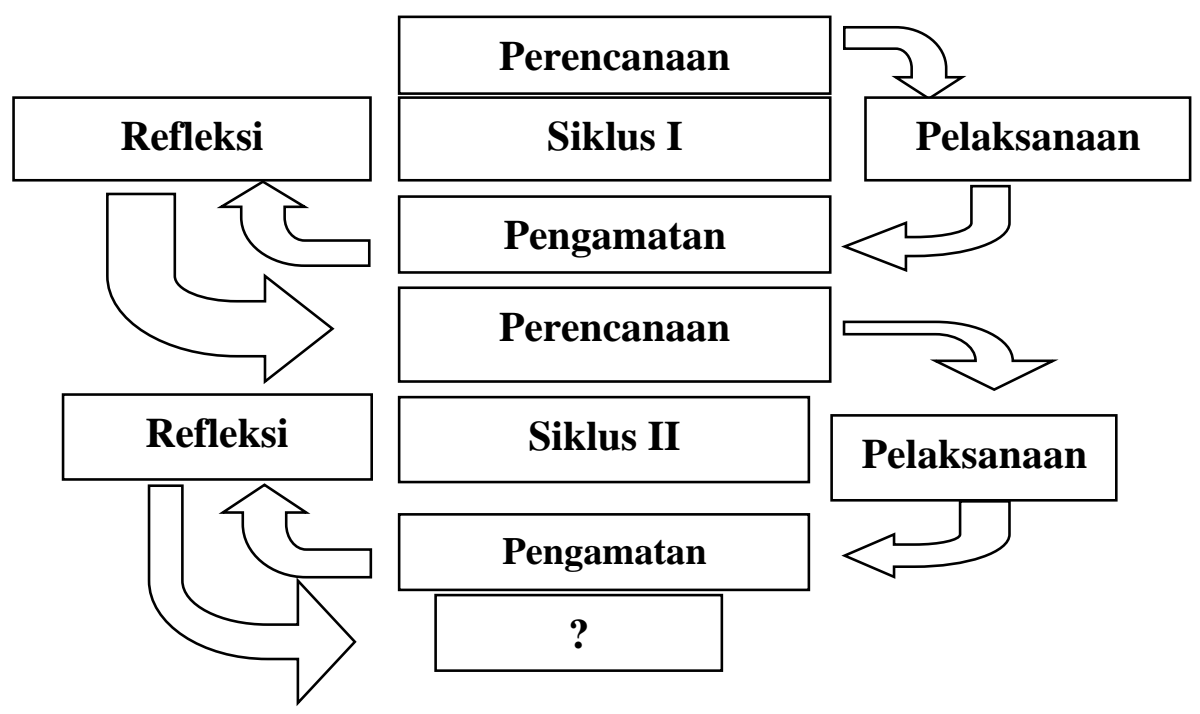

Materi ajar "Hidup Bersyukur" akan dipaparkan seturut Rancangan Pembelajaran yang disusun. Merujuk pada teori Slameto bahwa perlunya menyajika materi pokok untuk subjek pembelajaran (Slameto, 2016, 50), maka akan dipaparkan pokok materi di maksud dalam tabel di bawah ini. Materi dipersiapan untuk Siklus I dan Siklus II.

Tabel 1. Kisi-kisi Instrumen:

Pengertian Apakah Arti Hidup Bersyukur (Silkus I)

\begin{tabular}{lllll}
\hline \multirow{2}{*}{ No } & \multicolumn{1}{c}{ Indikator } & \multicolumn{2}{c}{ Nomor Item } & Jumlah \\
\cline { 3 - 5 } & & C1 & C2 & \\
\hline 1. & Memahami Arti Bersyukur & $1,3,7,11,15$ & 14 & 6 \\
\hline 2. & $\begin{array}{l}\text { Memahami Makna Hidup Bersyukur } \\
\text { dalam Segala Hal }\end{array}$ & $2,5,6,12,13$ & $4,8,9,10$ & 9 \\
\hline & Jumlah & 10 & 5 & 15 \\
\hline
\end{tabular}

Keterangan: C1: Pengetahuan

C2: Pemahaman 
Tabel 2. kisi-kisi instrumen (Siklus II)

\begin{tabular}{lllll}
\hline No & \multicolumn{1}{c}{ Indikator } & \multicolumn{2}{c}{ Nomor Item } & Jumlah \\
\cline { 3 - 5 } & & C1 & C2 & \\
\hline $\begin{array}{l}\text { 1. } \\
\text { Memahami arti dari hidup dalam } \\
\text { bersyukur }\end{array}$ & $1,8,14$ & $3,4,6,7$ & 7 \\
\hline $\begin{array}{l}\text { Pendalaman Alkitab mengenai hidup } \\
\text { bersyukur }\end{array}$ & $2,5,9,10$, & $12,13,15$ & 8 \\
\hline & 11 & & & \\
\hline
\end{tabular}

Keterangan: C1: Pengetahuan

C2: Pemahaman

\section{Hasil dan Pembahasan}

Dalam setiap siklus dilaksanakan dalam sekali pertemuan. Pertemuan ini dilakukan pada hari Senin 22 September 2019. Pada tahap ini merupakan pelaksanaan dari RPP yang sudah didesain mengikuti model pembelajaran Think-Pair-Share (TPS). Tindakan pada pra siklus dilakukan dalam tiga tahap, yaitu: tahap pendahuluan, tahap inti, dan tahap penutup. Pelaksanaan tindakan berdasarkan metode ceramah dan tanya jawab yakni:

1. Kegiatan awal
a) Nyanyi, berdoa dan membaca Alkitab dipimpin oleh 2 orang
b) Mengabsen siswa
c) Guru menjelaskan topik pelajaran yang akan dipelajari dan tujuannya

2. Kegiatan inti
a) Guru mengajarkan apa pengertian dan makna hidup bersyukur
b) Guru memberikan kesempatan kepada siswa untuk bertanya atau guru yang memberi pertanyaan.
c) Guru menjawab pertanyaan siswa

3. Kegiatan penutup
a) Guru meminta pertanyaan dan tanggapan siswa sebagai bukti bagi guru untuk menilai apakah siswanya masih ada yang belum memahami materi yang sudah dipelajari.
b) Guru mengumpulkan materi yang telah dibagi dan membagikan soal untuk dijawab siswa (sebagai penelitian).
c) Bernyanyi dan berdoa oleh siswa. 


\section{Tindakan pengamatan (Observation)}

Pengamatan ini dilakukan oleh observer berupa pengamatan terhadap aktivitas siswa dengan butur lembar observasi Pengamat melaporkan apa yang dilakukan siswa dan guru selama proses berlangsung.

1. Kemampuan guru dalam mengorganisasikan siswa masih perlu perbaikan karena siswa masih lalai sehingga waktu kurang efisien

2. Pada saat siswa mempelajari topik mereka masing-masing, beberapa siswa bertanya kepada guru seharusnya mereka berdisikusi dengan anggota kelompok.

3. Aktivitas yang diamati pada kelompok ahli dan kelompok asal dapat dilihat pada lembar observasi.

4. Kegiatan observasi dilaksanakan selama proses belajar mengajar berlangsung. Selama observasi, penelitian mencatat kegiatan proses pembelajaran yang berlangsung dan menilai hasil tindakan.

Tabel 3. Perolehan Nilai Hasil Belajar Siswa Pada Pra Siklus I

\begin{tabular}{ccccl} 
No. & Interval nilai & Fo & Fr\% & \multicolumn{1}{c}{ Keterangan } \\
\hline 1. & $90-100$ & 8 & 26,67 & Sangat tuntas \\
\hline 2. & $80-89$ & 7 & 23,33 & Tuntas \\
\hline 3. & $70-79$ & 8 & 26,67 & Cukup tuntas \\
\hline 4. & $<70$ & 7 & 23,33 & Tidak tuntas \\
\hline & Jumlah & 30 & 100 & \\
\hline
\end{tabular}

Gambar 1. Diagram Perolehan Hasil Belajar Pra-siklus I

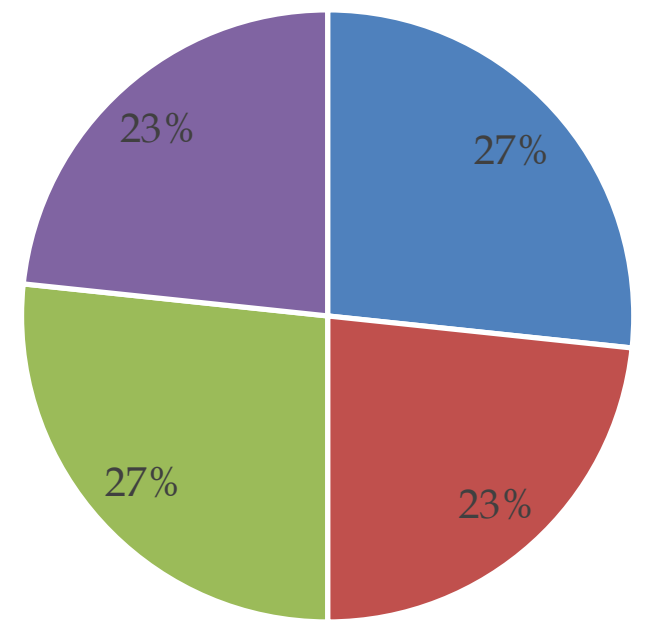

- Sangat tuntas $\square$ Tuntas $\square$ Cukup tuntas $\square$ Tidak tuntas 
Dari gambar di atas, hasil belajar yang diperoleh siswa pada waktu pelaksanaan tindakan selesai maka diketahui nilai hasil belajar siswa dengan kategori tindakan sangat tuntas sebanyak 8 orang $(26,67 \%)$, yang tuntas sebanyak 7 orang $(23,33 \%)$, yang cukup tuntas sebanyak 8 orang $(26,67 \%)$, dan yang tidak tuntas sebanyak 7 orang (23,33\%). Melalui hasil belajar siswa pada pra siklus I ini perlu dilakukan perbaikan kembali di siklus I dengan menggunakan model pembelajaran TPS. Diagram batang yang menunjukkan tingkat hasil belajar siswa selama proses belajar mengajar pada pra-siklus dapat dilihat pada gambar di atas.

Tabel 4. Perolehan Nilai Hasil Belajar Siswa Pada Pra Siklus

\begin{tabular}{ccccl}
\hline No. & Interval nilai & Fo & $\mathbf{F r} \%$ & \multicolumn{1}{c}{ Keterangan } \\
\hline 1. & $90-100$ & 7 & 23,33 & Sangat tuntas \\
\hline 2. & $80-89$ & 7 & 23,33 & Tuntas \\
\hline 3. & $70-79$ & 1 & 3,34 & Cukup tuntas \\
\hline 4. & $<70$ & 15 & 50 & Tidak tuntas \\
\hline & Jumlah & 30 & 10 & \\
\hline
\end{tabular}

Gambar 2. Diagram Perolehan Hasil Belajar Pra-siklus I

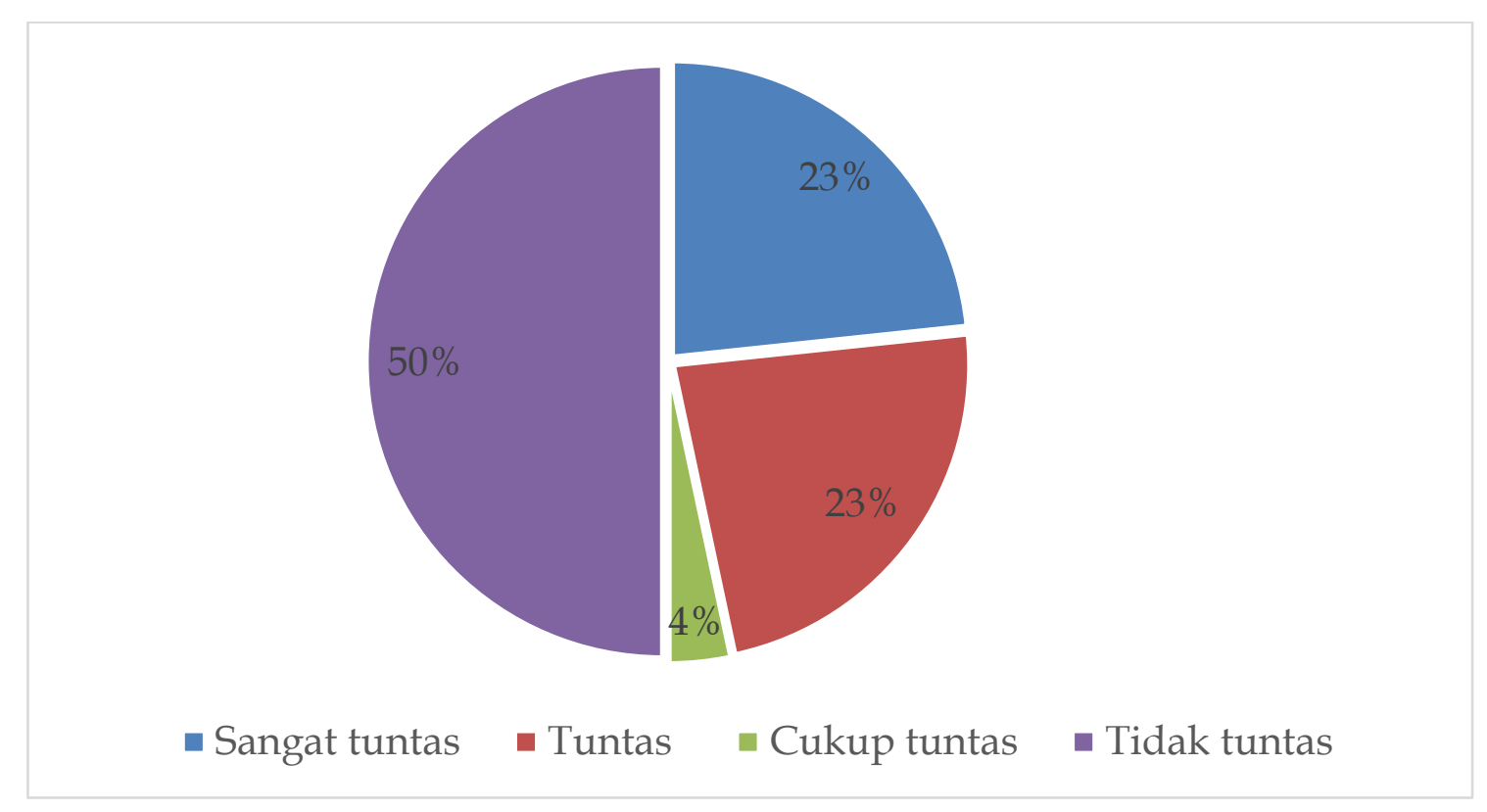

Dari gambar tersebut hasil belajar yang diperoleh siswa pada waktu pelaksanaan tindakan selesai maka diketahui nilai hasil belajar siswa dengan kategori tindakan sangat tuntas sebanyak 7 orang $(23,33 \%)$, yang tuntas sebanyak 7 orang $(23,33 \%)$, yang cukup tuntas sebanyak 1 orang $(3,34 \%)$, dan yang tidak tuntas sebanyak 15 orang $(50 \%)$. Melalui hasil belajar siswa pada pra 
siklus II ini perlu dilakukan perbaikan kembali di siklus I dengan menggunakan model pembelajaran Think-Pair-Share (TPS). Diagram batang yang menunjukkan tingkat hasil belajar siswa selama proses belajar mengajar pada pra-siklus dapat dilihat pada gambar di atas.

\section{Siklus I}

Hasil belajar siswa rendah maka dilakukan tindakan pada siklus pertama ini. Yang telah disiapkan pada siklus pertama ini yaitu beberapa perangkat pembelajaran dan instrumen peneltian. Perangkat pembelajaran yang dihasilkan adalah rencana pelaksanaan pembelajaran (RPP), bahan ajar (materi), dan lembar evaluasi. Adapun standar kompentensi (SK) yang dibahas dalam perangkat pembelajaran tersebut adalah "Hidup Bersyukur" dalam segala situasi.

Langkah-langkah yang disusun dalam RPP didesain sesuai dengan langkah-langkah pada model pembelajaran Think-Pair-Share (TPS). Bahan ajar merupakan kumpulan lembar berupa uraian materi dari soal-soal yang dibahas. Sedangkan lembar evaluasi berisi tentang soal-soal yang menyangkut pembahasan siswa tentang materi pembelajaran. Adapun tahap-tahap yang dilakukan sesuai dengan PTK yaitu:

Tahap perencanaan (Planning) Siklus I

a. Menyusun dan menyiapkan RPP dengan materi hidup bersyukur.

b. Menyiapkan bahan ajar yang akan dipakai

c. Merancang model pembelajaran Think-Pair-Share (TPS)

d. Membuat tes akhir

Pelaksanaan/Tindakan (Action) Siklus I

Dalam setiap siklus dilaksanakan dalam sekali pertemuan. Siklus kedua dilakukan pada hari selasa 23 November 2019. Tahap ini merupakan pelaksanaan dari RPP yang sudah didesain mengikuti pembelajaran Think-PairShare (TPS). Tindakan pada siklus II dilakukan dalam tiga tahap, yaitu: tahap pendahuluan, tahap inti, dan tahap penutup. Pelaksanaan tindakan berdasarkan langkah-langkah dalam strategi belajar inkuiri yakni:

a. Kegiatan awal

1) Nyanyi, berdoa dan membaca Alkitab dipimpin oleh 2 orang

2) Mengabsen siswa sembari mengumpulkan buku ibadah/ buku PR 
3) Guru menjelaskan topik pelajaran yang akan dipelajari dan tujuannya b. Kegiatan inti

Tabel 5. Kegiatan Pembelajaran Siklus I

\begin{tabular}{|c|c|c|}
\hline \multirow{2}{*}{$\begin{array}{l}\text { Langkah- } \\
\text { langkah }\end{array}$} & \multicolumn{2}{|c|}{ Kegiatan pembelajaran } \\
\hline & GURU & SISWA \\
\hline $\begin{array}{l}\text { Langkah } 1 \\
\text { Pendahulu } \\
\text { an }\end{array}$ & $\begin{array}{l}\text { Memberikan bahan bacaan } \\
\text { kepada siswa untuk dibaca. } \\
\text { Yaitu: "Hidup bersyukur } \\
\text { dalam segala situasi" }\end{array}$ & $\begin{array}{l}\text { Membaca selintas dengan } \\
\text { cepat untuk menemukan ide } \\
\text { pokok/tujuan pembelajaran } \\
\text { yang hendak dicapai. }\end{array}$ \\
\hline $\begin{array}{l}\text { Langkah } 2 \\
\text { Think }\end{array}$ & $\begin{array}{l}\text { a. Memberikan tugas kepada } \\
\text { siswa untuk membuat } \\
\text { penyelesaian } \\
\text { b. Menginformasikan ke- } \\
\text { pada siswa untuk berpikir } \\
\text { agar berusaha } \\
\text { menyelesaikan tugas yang } \\
\text { diberikan guru dengan } \\
\text { membuka buku, membaca } \\
\text { Alkitab dan mencari dari } \\
\text { sumber-sumber lain. }\end{array}$ & $\begin{array}{l}\text { a. Memperhatikan penjelasan } \\
\text { guru dan mulai untuk } \\
\text { berpikir dari tugas yang } \\
\text { diberikan guru.. } \\
\text { b. Membuka Alkitab. } \\
\text { c. Mencari dari sumber- } \\
\text { sumber lain. }\end{array}$ \\
\hline $\begin{array}{l}\text { Langkah } 3 \\
\text { Pair }\end{array}$ & $\begin{array}{l}\text { Membagi setiap siswa dengan } \\
\text { teman sebangukunya untuk } \\
\text { berdiskusi. }\end{array}$ & $\begin{array}{lr}\text { Berdiskusi } & \text { dengan } \\
\text { pasangannya mengenai } \\
\text { jawaban tugas yang } \\
\text { dikerjakan dari informasi } \\
\text { yang diberikan oleh guru } \\
\text { dengan pengetahuan yang } \\
\text { telah diketahui melalui bahan } \\
\text { bacaan. }\end{array}$ \\
\hline
\end{tabular}

Langkah 5 Meminta siswa secara acak Menjawab pertanyaan-

Share untuk berbagi pendapat pertanyaan yang telah diminta kepada teman lainnya di oleh guru untuk saling berbagi dalam kelas. jawaban dengan temannya yang lain.

Langkah 6 Siswa dinilai secara individual Membaca kembali bahan Penghar- dan kelompok bacaan siswa jika masih belum 
c. Kegiatan penutup

dibuatnya.

1) Guru meminta pertanyaan dan tanggapan siswa sebagai bukti bagi guru untuk menilai apakah siswanya masih ada yang belum memahami materi yang sudah dipelajari dan guru menyimpukkan dari materi yang disampaikan.

2) Bernyanyi dan berdoa oleh siswa.

Tindakan Pengamatan (Observation) Siklus I

Pada pengamatan ini, dilakukan oleh observer berupa pengamatan terhadap hasil belajar siswa berdasarkan jawaban dari butir soal yang telah diberikan peneliti. Apakah nilai siswa telah meningkat dari pra siklus atau malah menurun dari nilai pra siklus.

Tabel 6. Perolehan nilai hasil belajar siswa pada siklus I

\begin{tabular}{ccccl}
\hline No & Interval Nilai & Fo & Fr $(\%)$ & \multicolumn{1}{c}{ Keterangan } \\
\hline 1. & $90-100$ & 0 & - & Sangat tuntas \\
\hline 2. & $80-89$ & 1 & 3,33 & Tuntas \\
\hline 3. & $70-79$ & 0 & - & Cukup tuntas \\
\hline 4. & $<70$ & 29 & 96,67 & Tidak tuntas \\
\hline & Jumlah & 30 & 100 & \\
\hline
\end{tabular}

Gambar 3 Diagram Perolehan Hasil Belajar Siklus I

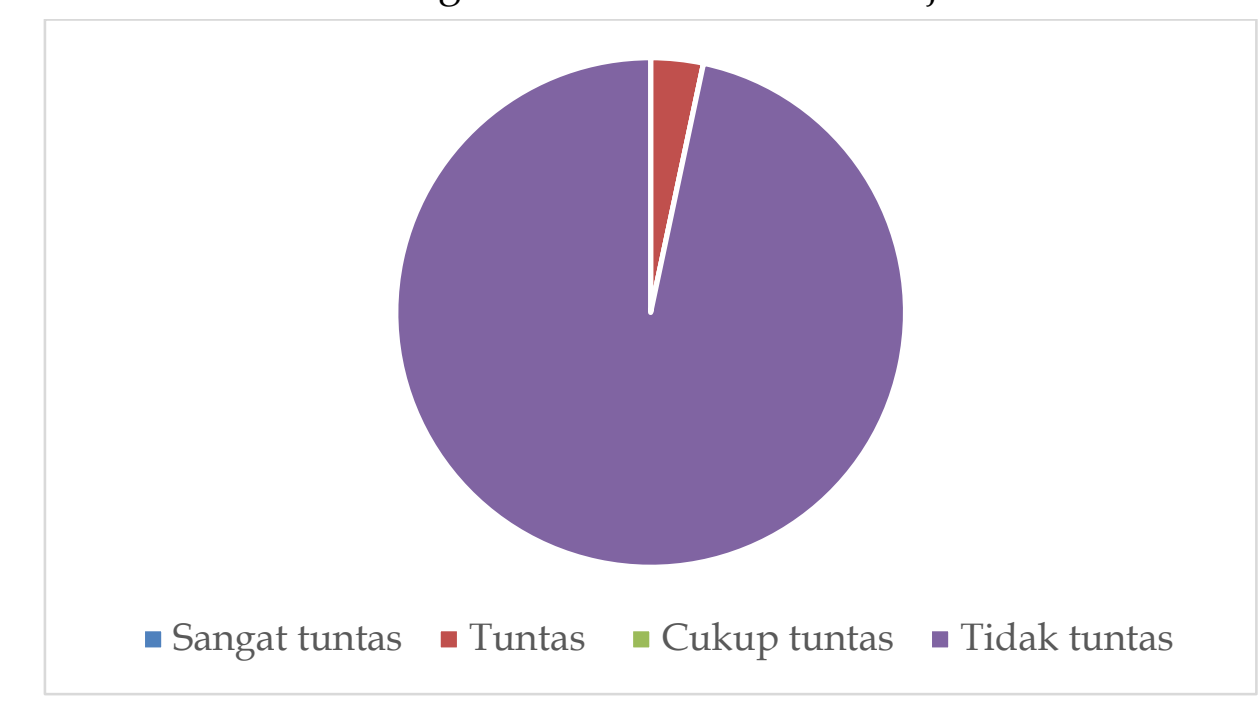




\section{Refleksi Siklus I}

Dengan memperhatikan data observasi hasil belajar terhadap siswa kelas VIII SMP, diperoleh hal-hal sebagai berikut. Dari tabel 3 hasil belajar PAK siswa pada saat Siklus I, didapat 0 siswa yang sangat tuntas atau (0\%), 1 siswa yang tuntas atau (3,33\%), 0 siswa yang cukup tuntas (0\%), dan 29 siswa yang tidak tuntas (96,67\%), sehingga perlu menerapkan model belajar yang lebih maksimal supaya hasil belajar PAK semakin meningkat. Untuk itu, peneliti melakukan model pembelajaran Think-Pair-Share (TPS). Dalam pembelajaran, karena hanya 3,33\% yang tuntas maka perlu dilakukan Siklus II dengan model pembelajaran Think-Pair-Share (TPS).

\section{Siklus II}

Setelah memperhatikan siklus pertama, hasil belajar siswa sudah mulai meningkat. Namun, perlu dilanjutkan ke siklus II untuk melihat apakah model pembelajaran Think-Pair-Share (TPS) berhasil meningkatkan hasil belajar atau tidak berhasil. Untuk itu, maka dilakukan tindakan pada siklus kedua ini. Yang telah disiapkan pada siklus kedua ini beberapa perangkat pembelajaran dan instrumen penelitian. Perangkat pembelajaran yang dihasilkan adalah rencana pelaksanaan pembelajaran (RPP), bahan ajar (materi), lembar evaluasi. Adapun standar kompetensi (SK) yang dibahas dalam perangkat pembelajaran tersebut adalah hidup bersyukur dalam berpengharapan serta mewujudkan hidup beriman.

Langkah-langkah yang disusun dalam RPP didesain sesuai dengan langkah-langkah pada model pembelajaran Think-Pair-Share (TPS). Bahan ajar merupakan kumpulan lembar berupa uraian materi dari topik-topik yang dibahas. Sedangkan lembar evaluasi berisi tentang soal-soal yang menyangkut pemahaman siswa tentang materi pelajaran. Adapun tahap-tahap yang dilakukan sesuai dengan PTK yaitu:

Tahap perencanaan (planning) Siklus II

a. Menyusun dan menyiapkan RPP dengan materi adalah hidup bersyukur dalam berpengharapan serta mewujudkan hidup beriman.

b. Menyiapkan bahan ajar yang akan dipakai

c. Merancang model pembelajaran Think-Pair-Share (TPS)

d. Membuat tes akhir 
Pelaksanaan/Tindakan (action) Siklus II

Dalam setiap siklus dilaksanakan dalam sekali pertemuan. Siklus kedua dilakukan pada hari selasa 29 September 2015. Tahap ini merupakan pelaksanaan dari RPP yang sudah didesain mengikuti strategi belajar Inkuiri. Tindakan pada siklus II dilakukan dalam tiga tahap, yaitu: tahap pendahuluan, tahap inti, dan tahap penutup. Pelaksanaan tindakan berdasarkan langkahlangkah dalam penerapan model pembelajaran Think-Pair-Share (TPS) yakni:

a. Kegiatan awal

1) Nyanyi, berdoa dan membaca Alkitab dipimpin oleh 2 orang

2) Mengabsen siswa sembari mengumpulkan buku ibadah/ buku PR

3) Guru menjelaskan topik pelajaran yang akan dipelajari dan tujuannya

b. Kegiatan inti

Tabel 7. Kegiatan Pembelajaran Siklus II

\begin{tabular}{|c|c|}
\hline Langkah- & Kegiatan pembelajaran \\
\hline langkah & Siswa \\
\hline $\begin{array}{l}\text { Langkah } 1 \\
\text { Pendahul } \\
\text { uan }\end{array}$ & $\begin{array}{l}\text { Memberikan bahan bacaan } \text { Membaca selintas dengan cepat } \\
\text { kepada siswa untuk dibaca. untuk menemukan ide pokok/ } \\
\text { Yaitu: "hidup bersyukur tujuan pembelajaran yang } \\
\text { dalam berpengharapan serta hendak dicapai. } \\
\text { mewujudkan hidup beriman" }\end{array}$ \\
\hline $\begin{array}{l}\text { Langkah } 2 \\
\text { Think }\end{array}$ & 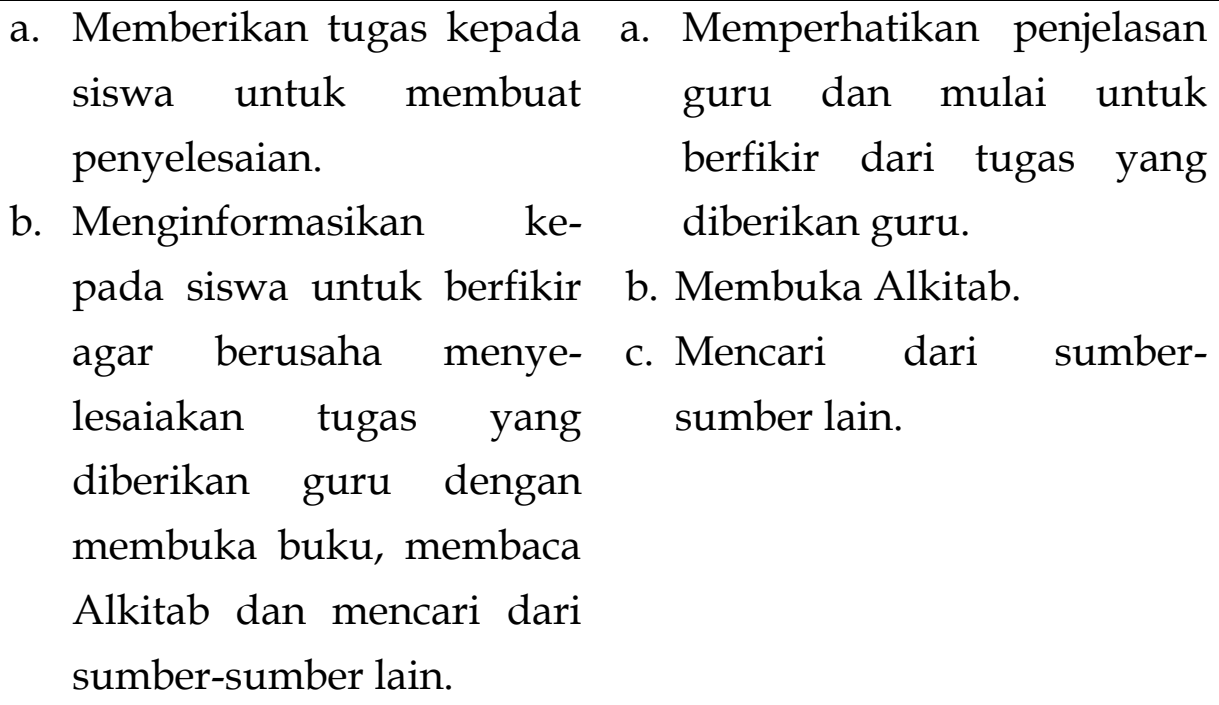 \\
\hline $\begin{array}{l}\text { Langkah } 3 \\
\text { Pair }\end{array}$ & $\begin{array}{lll}\text { Membagi setiap siswa dengan } & \text { Berdiskusi dengan pas- } \\
\text { teman sebangukunya untuk } & \text { angannya mengenai jawaban } \\
\text { berdiskusi. } & \text { tugas yang dikerjakan dari } \\
& \text { informasi yang diberikan oleh }\end{array}$ \\
\hline
\end{tabular}




\begin{tabular}{|c|c|c|}
\hline & & $\begin{array}{l}\text { guru dengan pengetahuan } \\
\text { yang telah diketahui melalui } \\
\text { bahan bacaan. }\end{array}$ \\
\hline $\begin{array}{l}\text { Langkah } 5 \\
\text { Share }\end{array}$ & $\begin{array}{l}\text { Meminta siswa secara acak } \\
\text { untuk berbagi pendapat } \\
\text { kepada teman lainnya di } \\
\text { dalam kelas. }\end{array}$ & $\begin{array}{l}\text { Menjawab pertanyaan- } \\
\text { pertanyaan yang telah diminta } \\
\text { oleh guru untuk saling berbagi } \\
\text { jawaban dengan temannya } \\
\text { yang lain. }\end{array}$ \\
\hline $\begin{array}{l}\text { Langkah } 6 \\
\text { Penghar- } \\
\text { gaan }\end{array}$ & $\begin{array}{l}\text { Siswa dinilai secara individual } \\
\text { dan kelompok }\end{array}$ & $\begin{array}{l}\text { Membaca kembali bahan } \\
\text { bacaan siswa jika masih belum } \\
\text { yakin akan jawaban yang telah } \\
\text { dibuatnya. }\end{array}$ \\
\hline
\end{tabular}

c. Kegiatan penutup

1) Guru meminta pertanyaan dan tanggapan siswa sebagai bukti bagi guru untuk menilai apakah siswanya masih ada yang belum memahami materi yang sudah dipelajari dan guru menyimpulkan dari materi yang disampaikan.

2) Bernyanyi dan berdoa oleh siswa.

Tindakan pengamatan (Observation) Siklus II

Pengamatan ini dilakukan oleh observer berupa pengamatan terhadap hasil belajar siswa berdasarkan jawaban dari butir soal yang telah diberikan peneliti. Apakah nilai siswa telah meningkat dari pra siklus atau malah menurun dari nilai pra siklus.

Tabel. 8 Perolehan Nilai Hasil Belajar Siswa pada Siklus II

\begin{tabular}{ccccc}
\hline No & Interval Nilai & Fo & Fr\% & Keterangan \\
\hline 1. & $90-100$ & 17 & 56,67 & Sangat tuntas \\
\hline 2. & $80-89$ & 3 & 10 & Tuntas \\
\hline 3. & $70-79$ & 4 & 13,33 & Cukup tuntas \\
\hline 4. & $<70$ & 6 & 20 & Tidak tuntas \\
\hline & Jumlah & 30 & 100 & \\
\hline
\end{tabular}


Gambar 3 Diagram Perolehan Hasil Belajar Siklus II

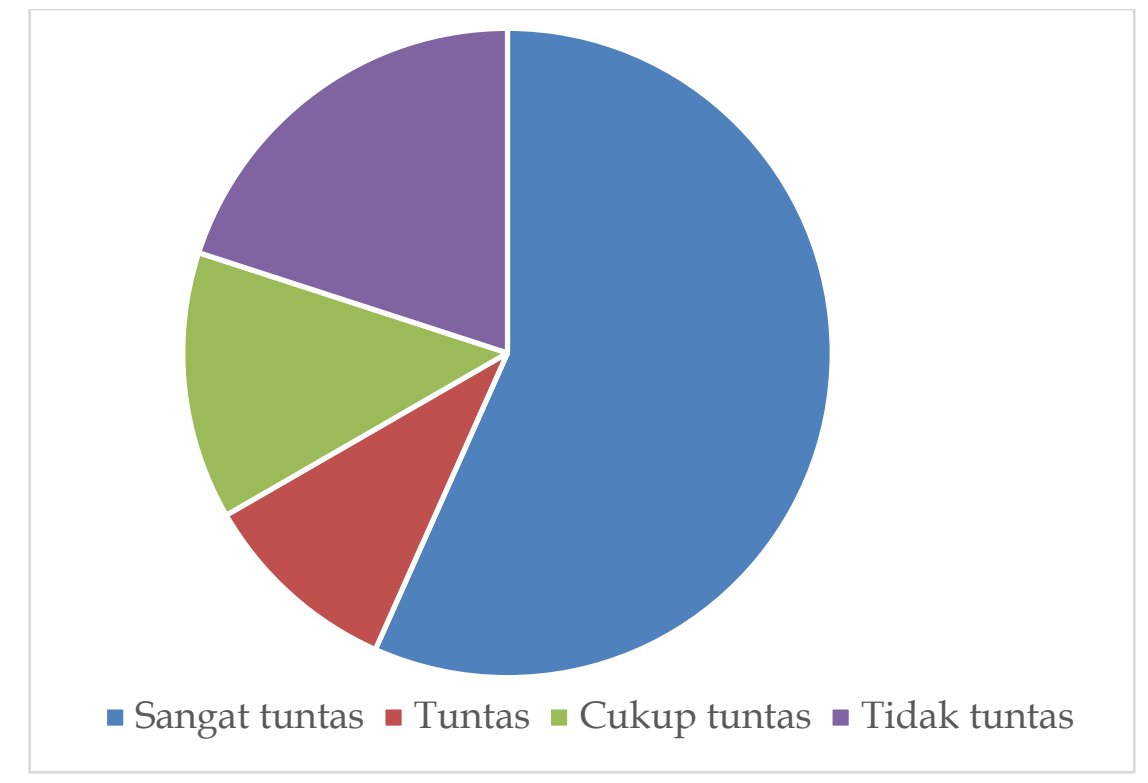

\section{Refleksi Siklus II}

Adapun keberhasilan yang diperoleh pada siklus II ini adalah sebagai berikut. Dari hasil belajar yang diperoleh siswa pada waktu pelaksanaan tindakan selesai, maka diketehui nilai hasil belajar siswa dengan kategori sangat tuntas 17 orang (56,67\%), yang tuntas sebanyak 3 orang $(10 \%)$, dan yang cukup tuntas 4 orang (13,33\%), dan yang tidak tuntas 6 orang (20\%). Melalui hasil belajar siswa pada pra siklus, siklus I dan II ini, maka peneliti tidak melanjutkan lagi ke siklus III. Karena hasil belajar siswa sudah terbukti meningkat melalui penerapan model pembelajaran Think-Pair-Share (TPS).

\section{Upaya Meningkatkan Pembelajaran PAK dengan Model Pembelajaran TPS di Sekolah Menengah Pertama}

Pembelajaran PAK di Sekolah Menengah Pertama mulai diajarkan sejak kelas VIII, tetapi pada kenyataannya pengajaran PAK mempengaruhi minat belajar sehinga setiap hasil belajar siswa rendah. Meningkatkan hasil belajar adalah segmen tersendiri yang diinginkan oleh peserta didik dan pendidik di dalam semua tingkat kegiatan pembelajaran. Demikian juga dalam Pendidikan Agama Kristen (PAK). Dalam hal ini, berarti guru, khususnya guru Pendidikan Agama Kristen (PAK) juga dituntut untuk memacu siswa menjadi seorang pembelajar yang seutuhnya. Guru dituntut menjadi tenaga edukatif yang kreatif. 
Namun kenyataannya, dalam kegiatan pembelajaran sehari-hari yang dilakukan di dalam pertemuan di kelas, masih banyak guru Pendidikan Agama Kristen yang tidak mampu merancang model pembelajaran yang mampu menjawab kebutuhan belajar siswa. Guru Pendidikan Agama Kristen hanya menerapkan model pembelajaran konvensional (tradisional) atau yang dikenal dengan model pembelajaran langsung (direct learning), yakni model pembelajaran dengan menggunakan metode ceramah, yang dilakukan secara monoton. Karena model pembelajaran ini sangat terkesan lemah. Oleh karena itu, dari permasalahan yang terjadi, penggunaan model pembelajaran kooperatif diharapkan perlu dikuasai dan diterapkan oleh guru Pendidikan Agama Kristen (PAK) pada kegiatan pembelajaran, baik yang berlangsung di dalam atau luar ruang kelas. Di luar ruangan akan membantu guru dalam praksis teologi yang diajarkannya, misalnya bagaimana hidup bersyukur sesuai materi ajar. Praktik di luar kelas mendorong siswa berpikir kreatif karena tuntutan dalam perilaku adalah konsekuensi dari teologi (ajaran) yang diterima di kelas (Panggabean, 2018, 173).

Sehubungan dengan permasalahan yang sering dihadapi oleh tenaga pendidik terutama guru Pendidikan Agama Kristen (PAK), model TPS diduga cocok diterapkan dalam ruang lingkup Pendidikan Agama Kristen di sekolah (di dalam dan di luar ruangan kelas), karena sesuai dengan judul materi pada pembahasam pembelajaran PAK demi tercapainya tujuan Pendidikan Agama Kristen itu sendiri dengan topik "Hidup Bersyukur."

\section{Langkah-langkah Model TPS dalam Pembelajaran PAK}

Dari penerapan di atas, maka akan diusulkan langkah-langkah model pembelajaran PAK dengan model TPS seperti dalam tabel di bawah.

Tabel 9. Langkah-langkah Model Pembelajaran Kooperatif Giat Guru

\begin{tabular}{ll}
\hline \multicolumn{1}{c}{ Fase } & \multicolumn{2}{c}{ Tingkah Laku Guru } \\
\hline $\begin{array}{l}\text { Menyampaikan } \\
\text { tujuan dan }\end{array}$ & $\begin{array}{l}\text { Guru menyampaikan semua tujuan pelajaran yang } \\
\text { ingin dicapai pada pelajaran tersebut dan }\end{array}$ \\
\hline Memotivasi siswa & memotivasi siswa belajar \\
\hline $\begin{array}{l}\text { Mengorganisasi siswa } \\
\text { kedalam kelompok }\end{array}$ & $\begin{array}{l}\text { Guru menyajikan informasi kepada siswa dengan } \\
\text { jalan demonstrasi atau lewat bahan bacaan }\end{array}$ \\
\hline
\end{tabular}




\begin{tabular}{ll}
\hline kooperatif & kelompok agar melakukan transisi secara efisien \\
\hline $\begin{array}{l}\text { Membimbing } \\
\text { kelompok bekerja dan } \\
\text { belajar }\end{array}$ & $\begin{array}{l}\text { Guru membimbing kelompok-kelompok belajar } \\
\text { pada saat mereka mengerjakan tugas mereka }\end{array}$ \\
\hline Evaluasi & $\begin{array}{l}\text { Guru mengevaluasi hasil belajar tentang materi yang } \\
\text { telah dipelajari atau masing-masing kelompok } \\
\text { mempersentasekan hasil kerjanya }\end{array}$ \\
\hline $\begin{array}{l}\text { Memberi } \\
\text { penghargaan }\end{array}$ & $\begin{array}{l}\text { Guru mencari cara untuk menghargai baik upaya } \\
\text { maupun hasil belajar individu dan kelompok }\end{array}$ \\
\hline
\end{tabular}

Tabel 10. Tahapan di Kelas Model TPS

\begin{tabular}{|c|c|}
\hline $\begin{array}{l}\text { Langkah- } \\
\text { langkah }\end{array}$ & an Pembelajaran \\
\hline $\begin{array}{l}\text { Tahap } 1 \\
\text { Pendahuluan }\end{array}$ & $\begin{array}{l}\text { Guru menjelaskan aturan main dan batasan waktu untuk } \\
\text { tiap kegiatan, memotivasi siswa terlibat pada aktivitas } \\
\text { pemecahan masalah } \\
\text { Guru menjelaskan kompetensi yang harus dicapai oleh siswa }\end{array}$ \\
\hline $\begin{array}{l}\text { Tahap } 2 \\
\text { Think }\end{array}$ & $\begin{array}{l}\text { Guru menggali pengetahuan awal siswa melalui kegiatan } \\
\text { demonstrasi } \\
\text { Guru memberikan Lembar Kerja Siswa (LKS) kepada } \\
\text { seluruh siswa. Siswa mengerjakan LKS tersebut secara } \\
\text { individu }\end{array}$ \\
\hline $\begin{array}{l}\text { Tahap } 3 \\
\text { Pair }\end{array}$ & $\begin{array}{l}\text { Siswa dikelompokkan dengan teman sebangkunya } \\
\text { Siswa berdiskusi dengan pasangannya mengenai jawaban } \\
\text { tugas yang telah dikerjakan }\end{array}$ \\
\hline $\begin{array}{l}\text { Tahap } 4 \\
\text { Share }\end{array}$ & $\begin{array}{l}\text { Satu pasang siswa dipanggil secara acak untuk berbagi } \\
\text { pendapat kepada seluruh siswa di kelas dengan dipandu } \\
\text { oleh guru. }\end{array}$ \\
\hline $\begin{array}{l}\text { Tahap } 5 \\
\text { Penghargaan }\end{array}$ & Siswa dinilai secara individu dan kelompok \\
\hline
\end{tabular}

\section{Implikasi}

Peran guru dalam pembelajaran TPS adalah sebagai fasilitator, moderator, organisator, diretor-motivator, evaluator dan mediator terlihat jelas. Dalam kondisi ini, peran dan fungsi siswa terlihat bahwa adanya keterlibatan 
siswa yang dapat memberikan suasana aktif dan pembelajaran terkesan demokratis dan masing-masing punya peran dan akan memberikan pengalaman belajarnya kepada siswa lain (Hutahaean, 2019). Sebagai fasilitator, seorang guru harus memiliki sikap seperti, mampu menciptakan suasana kelas yang nyaman dan menyenangkan, membantu dan mendorong siswa untuk menggunakan dan menjelaskan keinginan dan pembicaraannya baik secara individual mampu kelompok dan juga membina agar setiap orang merupakan sumber yang bermanfaat bagi orang lain.

Sebagai mediator guru berperan sebagai penghubung dalam menjembatani dan mengaitkan materi pembelajaran yang sedang dibahas melalui pembelajaran TPS dengan permasalahan yang nyata ditemukan dilapangan. Peran ini sangat penting dalam menciptakan pembelajaran yang bermakna, disamping itu guru berperan menyediakan sarana pembelajaran agar suasana belajar tidak monoton dan membosankan. Sebagai directormotivator guru berperan dalam membimbing serta mengarahkan jalannya diskusi, membentuk kelancaran diskusi, tetapi tidak memberi jawaban (Nuhamara, 2018, 109). Sehingga karakter siswa, dalam hal ini memiliki rasa bersyukur dapat terbentuk dalam diri siswa.

Sebagai motivator, guru berperan sebagai pemberi semangat pada siswa untuk aktif dalam berpartisipasi peran ini sangat aktif dalam rangka memberikan semangat dan dorongan belajar kepada siswa dalam mengembangkan keberanian siswa baik dalam mengembangkan keahlian dalam bekerja sama yang meliputi mendengarkan dengan seksama, mengembangkan rasa empati dan kritis (Surayya \& Tika, 2014, 9), maupun berkomunikasi saat bertanya, mengemukakan pendapat dan mampu menyampaikan permasalahannya.

\section{Rekomendasi Untuk Penelitian Lanjutan}

Tim Peneliti memberikan saran kepada peneliti berikutnya; hasil penelitian ini dapat dijadikan acuan untuk melakukan penelitian lebih lanjut, untuk menentukan faktor-faktor lain yang dapat mendukung peningkatan hasil belajar. Melalui usaha ini, antara peneliti yang satu dengan peneliti yang lain dapat menunjukkan kinerja semakin baik dalam rangka meningkatkan hasil belajar dalam pembelajaran PAK. Kelemahan dari penelitian ini diharapkan dapat dihindarkan pada penelitian lanjutan. Kebutuhan akan rekan peneliti di lapangan untuk mencatat berbagai dinamika di kelas, jelas menjadi satu 
kendala selama penelitian. Sebab dinamika kelas mengalir baik dari sisi siswa maupun cuaca yang mempengaruhi riuh-rendah suara di dalam kelas. Mengingat lokasi SMP Parulian 3 persis di pinggir jalan raya, kota Medan. Berjalannya penelitian ini tentu atas support moril dari guru bidang PAK di SMP Parulian 3 Medan dan bpk. Bongsu Parhusip serta bpk. Hasahatan Hutahaean dari Sekolah Tinggi Teologi Sumatera Utara yang telah mengarahkan konsep, memeriksa data serta penyusunan laporan penelitian seperti naskah ini. Karena itu diucapkan terima kasih.

\section{Kesimpulan}

Setelah penemuan di atas, maka kesimpulan dari penelitian ini adalah bahwa pelaksanaan PTK pada pembelajaran mata pelajaran PAK di SMP Parulian 3 Medan dengan materi ajar "Hidup Bersyukur" dikategorikan cukup baik. Terbukti dari pelaksanaan penelitian tindakan kelas yang dilaksanakan secara prosedural dan adanya peningkatan yang lebih baik dari nilai maupun perilaku siswa. Kendala yang dihadapi dalam pelaksanaannya adalah kurang adanya kerja sama dari siswa untuk mengajarkan materi agama di rumah, sehingga kebanyakan siswa hanya belajar agama di sekolah saja.

Saran untuk Guru yakni; memberikan motivasi kepada siswa untuk aktif mengikuti proses pembelajaran dengan model kooperatif dalam meningkatkan hasil belajar. Kedua, mengevaluasi efisien dan efektivitas penerapan model pembelajaran kooperatif untuk meningkatkan hasil belajar sewaktu pembelajaran PAK berlangsung. Dan ketiga, memberikan motivasi kepada siswa dan memberikan penguatan kepada siswa yang sudah baik dalam hasil belajar, sehingga siswa dapat menunjukkan kinerja yang lebih baik. Sedangkan bagi siswa belum baik dalam hasil belajar, hendaknya aktif dalam mengikuti proses pembelajaran dan berusaha meningkatkan hasil belajar sehingga memperoleh hasil belajar yang optimal. Kedua, memiliki rasa senang untuk belajar PAK melalui pembelajaran kooperatif maupun penggunaan media yang tersedia. Ketiga, kepada siswa yang sudah baik dalam hasil belajar jangan merasa bosan untuk memberi contoh dengan cara belajar bersama (kelompok) dengan teman yang lain.

\section{Rujukan}

Arikunto, S. (2006). Prosedur Penelitian Tindakan Kelas. Bumi Aksara, 136(2), 23. 
Hamalik, O. (2007). Kurikulum dan Pembelajaran. Jakarta: Bumi Aksara.

Hutahaean, H. (2016). Lahir dan Berkembangnya Aliran-Aliran Gereja. In Gundari Ginting (Ed.), Sejarah dan Pertumbuhan Gereja (pp. 21-37). Medan: Prodi Teologi STTSU.

Hutahaean, H. (2019). Akselerasi Guru Teologi Profesional dan Bermutu. Medan.

Kaddoura, M. (2013). Think Pair Share: A teaching Learning Strategy to Enhance Students ' Critical Thinking. Education Research Quarterly, 36(4), 3-24. https://doi.org/0196-5042

Khasinah, S. (2015). Classroom Action Research. Pionir: Jurnal Pendidikan, 4(1), 107-114. https://doi.org/10.22373/pjp.v4i1.159

Kothiyal, A., Majumdar, R., Murthy, S., \& Iyer, S. (2013). Effect of think-pairshare in a large CS1 class: $83 \%$ sustained engagement. In B. Simon (Ed.), ICER 2013 - Proceedings of the 2013 ACM Conference on International Computing Education Research (pp. 137-144). New York: Association for Computing Machiner. https:/ / doi.org/10.1145/2493394.2493408

Naibaho, D. (2018). Peranan Guru Sebagai Fasilitator Dalam Perkembangan Peserta Didik. Jurnal Christian Humaiora, 2(1), 77-86. https://doi.org/10.46965/jch.v2i1.112

Nuhamara, D. (2018). Pengutamaan Dimensi Karakter Dalam Pendidikan Agama Kristen. Jurnal Jaffray, 16(1), 93-115. https:/ / doi.org/10.25278/jj71.v16i1.278

Panggabean, J. Z. Z. (2018). Pendekatan Praktis-teologis Dalam Fondasi Pendidikan Kristiani. Jurnal Teologi Dan Pendidikan Agama Kristes (KURIOS), 4(2), 167-181. https:/ / doi.org/10.30995/kur.v4i2.81

Pazmino, R. W. (2003). Theological Education with Hispanic Persons: Teaching Distinctiveness. Teaching Theology and Religion, 6(3), 138-145. https:/ / doi.org/10.1111/1467-9647.00165

Prahl, K. (2017). Best Practices for the Think-Pair-Share Active-Learning Technique Kristine Prahl. American Biology Teacher, 79(1), 3-8. https:/ / doi.org/10.1525/abt.2017.79.1.3

Raba, A. A. A. (2017). The Influence of Think-Pair-Share (TPS) on Improving Students' Oral Communication Skills in EFL Classrooms. Creative Education, 8(1), 12-23. https:// doi.org/10.4236/ce.2017.81002

Radhakrishna, R., \& Chikthimmah, N. (2012). TPS (think, pair and share) as an active learning strategy. NACTA Journal, 56(3), 82-55.

Rifai, R. (2017). Penerapan Metode Demonstrasi untuk Meningkatkan Hasil 
Belajar Pendidikan Agama Kristen Materi Pembelajaran Sakramen Perjamuan Kudus VIII SMP Negeri 17 Surakarta, Tahun 2015/2016. DUNAMIS: Jurnal Penelitian Teologi Dan Pendidikan Kristiani, 1(2), 171. https:/ / doi.org/10.30648/dun.v1i2.112

Saifulloh, M., Muhibbin, Z., \& Hermanto, H. (2012). Strategi Peningkatan Mutu Pendidikan Di Sekolah. Jurnal Sosial Humaniora, 5(2), 206-218. https:/ / doi.org/10.12962/j24433527.v5i2.619

Slameto, S. (2016). Penulisan Artikel Ilmiah Hasil Penelitian Tindakan Kelas.

Scholaria: Jurnal Pendidikan Dan Kebudayaan, 6(2), 46-57. https:/ / doi.org/10.24246/j.scholaria.2016.v6.i2.p46-57

Surayya, L., \& Tika, M. (2014). Pengaruh Model Pembelajaran Think Pair Share Terhadap Hasil Belajar IPA Ditinjau Dari Keterampilan Berpikir Kritis Siswa. Jurnal Pendidikan Dan Pembelajaran IPA Indonesia, 4(1), 1-11.

Tafonao, T. (2018). Peranan Media Pembelajaran Dalam Meningkatkan Minat Belajar Siswa. Jurnal Komunikasi Pendidikan, 2(2), 103-114. https://doi.org/10.32585/jkp.v2i2.113

Tendrita, M., Mahanal, S., \& Zubaidah, S. (2016). Pemberdayaan Keterampilan Berpikir Kreatif melalui Model Remap Think Pair Share. Proceeding Biology Education Conference (ISSN: ), 285-291. Malang: Universitas Negeri Malang. https://doi.org/2528-5742

Tety, T., \& Wiraatmadja, S. (2017). Prinsip-Prinsip Filsafat Pendidikan Kristen. Evangelikal: Jurnal Teologi Injili Dan Pembinaan Warga Jemaat, 1(1), 55-60. Retrieved from https://journal.sttsimpson.ac.id/index.php/EJTI/article/view/56

Trianto. (2014). Model Pembelajaran Terpadu. Konsep Strategi Dan Implementasinya Dalam KTSP, 56.

Widayati, A. (2014). Penelitian Tindakan Kelas. Jurnal Pendidikan Akuntansi Indonesia, 6(1), 87-93. https:// doi.org/10.21831/jpai.v6i1.1793 